\title{
DETERMINATION OF THE CAVITATION IN FLUENCE ON THE DESTRUCTION PROCESS OF MICROORGANISM CELLS AGGLOMERATES
}

\author{
Volodymyr Starchevskyy1, Nataliya Bernatska1, *, \\ Iryna Typilo ${ }^{1}$, Lilianna Oliynyk ${ }^{1}$, Roman Kvit ${ }^{1}$
}

https://doi.org/10.23939/chcht12.04.462

\begin{abstract}
The influence of cavitation on a decrease of the number of microorganism colonies has been investigated. Our results have shown that the number of viable microorganisms in water dispersion during first 30 minutes of sonication increased till maximum. Then their quantity sharply decreased. A kinetic model of ultrasonic degradation of yeast cells aggregates was proposed.
\end{abstract}

Keywords: ultrasound, Saccharomyces cerevisiae, destruction of microorgnisms, yeast cells aggregate, kinetics.

\section{Introduction}

Sewage waters clearing is an important environmental problem of the national economy of any country, ignoring of which may lead to significant negative consequences in the form of nationwide environmental disaster [1-3]. The problem of sewage waters clearing is especially important for Ukraine, where due to the use of out-of-date technologies most sewage waters are characterized by a high level of chemical and biological contamination [4]. One of the main sources of contamination of the water environment is food industry enterprises. A vast majority of sewage waters is emptied uncleared to the natural water bodies, absorption fields or canalization, creating a significant environmental load $[5,6]$.

The need for searching of new technologies of sewage water clearing is proved by a poor effectiveness of the existing sewage treatment facilities. The use of classical technology of biological clearing involves highenergy costs and creation of surplus biomass, which causes filter clogging of waste treatment facilities and requires additional expenditures for its recovering [7]. Sewage water of food industry enterprises contains a considerable amount of biological and chemical contamination that is why after it is emptied to the surface

\footnotetext{
${ }^{1}$ Lviv Polytechnic National University

12, S. Bandera St., 7903 Lviv, Ukraine

* bernatska.nati@gmail.com

(C) Starchevskyy V., Bernatska N., Typilo I., Oliynyk L., Kvit R., 2018
}

water bodies there continues a range of chemical and biological transformations, which has a negative effect on the environment [8].

The use of the cavitation technologies may become the alternative to the existing methods of sewage water contamination level decrease. Ecological safety, high level of adaptability to the existing technologies and effectiveness allows using the cavitation technologies both as the main and the additional methods of intensification of sewage waters clearing and significantly reduce a technogenic pollution of the hydrosphere [9].

Sonication of well-dispersed microorganisms leads to their partial or full destruction $[10,11]$. Reduction of bacteria E. coli concentrated in the craters, where cavitation was generated till 1000 times, was observed [10]. The pseudo first order process [11] decreases the concentration of Saccharomyces cerevisiae during ultrasonic treatment. The rate constant of microorganism inactivation as a function of the vibration amplitude was similar to that of hydrogen peroxide formation in the distilled water. The inactivation of microorganisms can be connected with their treatment by hydroperoxide radicals formed from water in the result of growth and collapse of microscopic bubbles under the cavitation conditions [2, 12].

Cytologic investigation of Saccharomyces cerevisiae treated by ultrasound (US) [10] showed that main changes were observed inside of cells. Mechanical deformation and partial destruction of nuclea and vacuola structures take place in a short time of sonication. The cell walls are broken and the cell content is washed away at the second stage of the ultrasonic treatment. Further oxidation of organic substances proceeds by the pseudofirst order reaction [9]. There is a need to note that the rate constant of this reaction depends on the strength of bonds between hydrogen and carbon atoms in organic compounds or their redox potential [11, 13].

The aim of our investigation was the comparison of the mechanical influence of acoustic cavitation (AC) on the destruction of Saccharomyces cerevisiae colonies in water dispersion. 


\section{Experimental}

Ultrasound transducer UZDN-2T (Fig. 1) with working frequency of $22 \mathrm{kHz}$ and power of $40 \mathrm{~W} / \mathrm{min}$ was used. Dry Saccharomyces cerevisiae were dispersed in 11 of distilled water by mixing at $8 \mathrm{~min}^{-1}$ for $1 \mathrm{~h}$ at room temperature. The obtained dispersion contained $1-8 \%$ of dry Saccharomyces cerevisiae. The most probable number (MPN) of viable microorganisms was investigated in each sample. The MPN was determined by surface planting on the meat-peptone agar medium before and after treatment. Two plates were used for each dilution and incubated at $310 \mathrm{~K}$ for $48 \mathrm{~h}$. The influence of ultrasound was measured for 4 different concentrations of yeast cells at different treatment time and at $309 \mathrm{~K}$. The radius of yeast aggregates in dispersion was determined by sedimentation method according to [14].

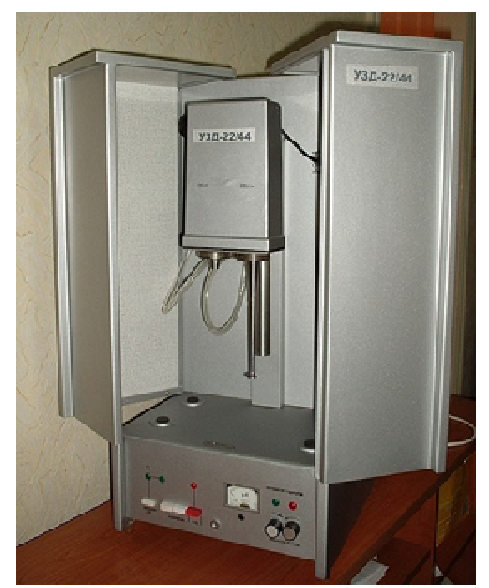

Fig. 1. Ultrasonic generator UZDN-2T

for combustion of of organic matters inclusions and microorganisms disinfection in the ultrasonic field

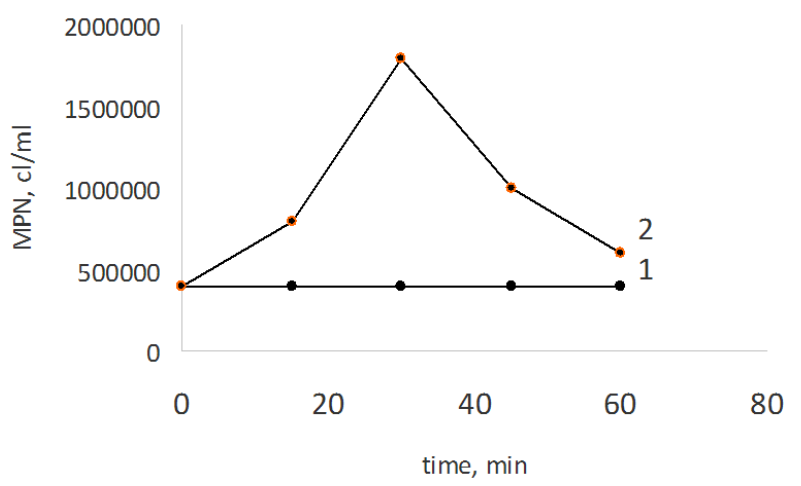

Fig. 2. Dependence of the number of viable Saccharomyces cerevisiae in the unite volume of dispersion on time during sonication (1) and without it (2). Initial concentration of yeast was $1.6 \mathrm{~g} / 1$

\section{Results and Discussion}

Investigations of the number of viable microorganisms in unite volume of dispersion after dispergation of dry Saccharomyces cerevisiae during sonication have shown (Fig. 2) that their concentrations increased during first 30 min till maximum. Then their quantity sharply decreased in comparison with untreated cells.

It should be noted that the part of microorganisms was viable in this condition. Investigation of aggregate size by sedimentation method showed (Fig. 3) that average radius of aggregates found by the sedimentation method decreased during 30 min of sonication.

Mechanism of destruction of agglomerates of microorganisms can be described considering that the ultrasound energy is spent on the formation of a new surface of contact with media when aggregate is broken.

Volume of aggregate can be calculated according to Eq. (1):

$$
V=4 \pi R^{3} / 3
$$

where $R$ - the radius of aggregate found by the sedimentation method.

The number of aggregates in the unit volume of dispersion is equal to:

$$
N=c /(V \rho)
$$

where $c$ - the initial concentration of Saccharomyces cerevisiae in dispersion, $\mathrm{g} / \mathrm{l} ; \rho-$ the density of swelling microorganisms, $\mathrm{g} / \mathrm{cm}^{3}$.

Fig. 4 shows that the number of aggregates of microorganisms in the unit volume of dispersion rises up practically linear in time till $30 \mathrm{~min}$. It coincides with microbiological data (Fig. 2). The rate of new aggregate formation is increased when the initial concentration of Saccharomyces cerevisiae in dispersion is increased.

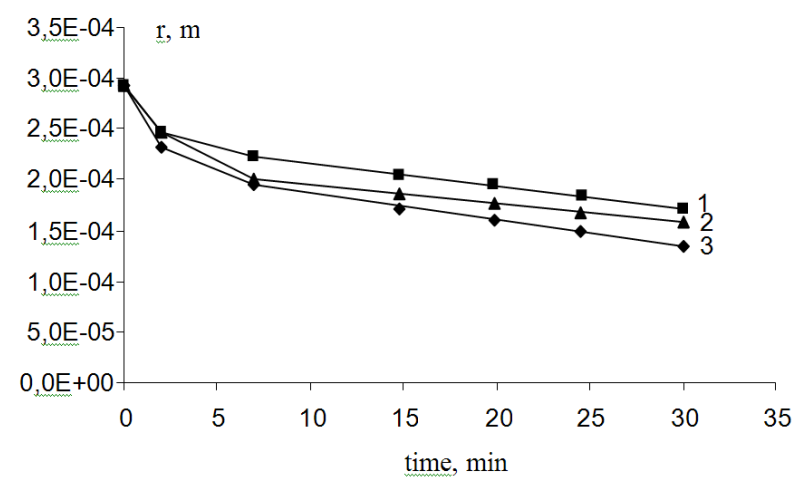

Fig. 3. The change of the radius of the aggregate of yeast dispersion in time during sonication. Initial concentrations of yeast $1.6 \mathrm{~g} / \mathrm{l}(1), 4 \mathrm{~g} / \mathrm{l}$ in aerobic (2) and anaerobic condition (3) 


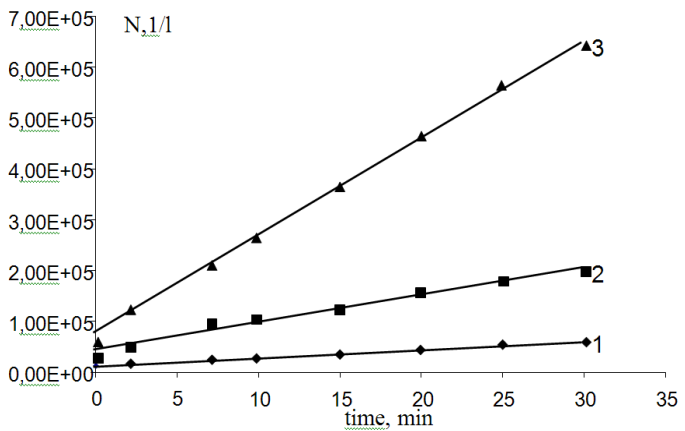

Fig. 4. Dependence of the number of Saccharomyces cerevisiae aggregates in the unit volume in time during ultrasonic irradiation. Initial concentrations of yeast are $1.6(1)$, 4 (2) and 8 (3) g/l

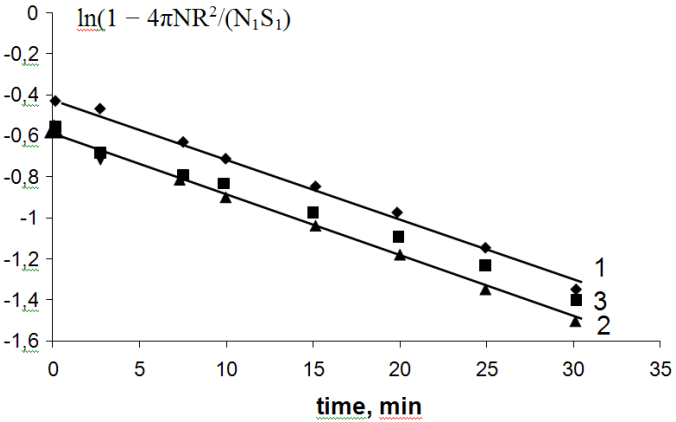

Fig. 5. Dependence of the number of Saccharomyces cerevisiae aggregates in the unit volume of dispersion in time in coordinates according to Eq. (7). Initial concentrations of yeast are 4 (1), $1.6(2)$ and 8 (3) g/l

Correlation coefficients and rate constants of microorganism aggregates dispersion under ultrasonic treatment

\begin{tabular}{|c|c|c|c|}
\hline$c, \mathrm{~g} / \mathrm{l}$ & $R$ & $\ln \left(1-4 \pi N_{0} R_{0}^{2}\left(N_{1} S_{1}\right)\right.$ & $k, \mathrm{~s}^{-1}$ \\
\hline 8.0 & 0.988 & $0.47 \pm 0.05$ & $0.029 \pm 0.002$ \\
\hline 4.0 & 0.961 & $0.63 \pm 0.07$ & $0.030 \pm 0.004$ \\
\hline 1.6 & 0.987 & $0.60 \pm 0.05$ & $0.026 \pm 0.004$ \\
\hline
\end{tabular}

Taking into account that elimination of ultrasound energy is constant in time, the rate of formation of new surface of aggregate at its distraction is proportional to the surface area participating in the formation of bonds between particles in aggregate:

$$
d S_{n} / d t=-k S_{n} N
$$

where $k$ - the rate constant of new surface area formation; $S_{n}$ - the surface participating in bonds formation between particles in aggregate in unit volume of dispersion.

Eq. (4) can be obtained by integration of Eq. (3):

$$
\ln \left(S_{n} / S_{n 0}\right)=-k t
$$

where $S_{n 0}$ - initial surface participating in bonds formation between particles in aggregate in the unit volume of initial dispersion.

$$
S_{n}=N_{1} S_{1}-N S_{a}
$$

where $N_{1}$ - the whole number of microorganisms in aggregate or simple bacteria; $S_{1}$ - the surface area of one simple bacteria; $S_{a}$ - outside surface area of cell aggregate.

$$
S_{a}=4 \pi R^{2}
$$
obtained:

From Eqs. (4)-(6) the next equation can be

$$
\ln \left(1-4 \pi N R^{2} /\left(N_{1} S_{1}\right)=\ln \left(1-4 \pi N_{0} R_{0}^{2} /\left(N_{1} S_{1}\right)-k t\right.\right.
$$

where $N_{0}$ and $R_{0}$ are the initial concentrations of aggregates in dispersion and their radius.

Fig. 5 shows that the experimental data or the concentration of aggregates of microorganisms and their radius lie on the straight lines in the coordinates of Eq. (7).

The rate constants $k$ (Table) for different initial concentration of cells in dispersion are close to each other. Correlation coefficient of the straight lines are higher than critical (0.878) for significance level (0.05). Therefore, the kinetic model describes the process of decomposition of aggregates with new surface formation.

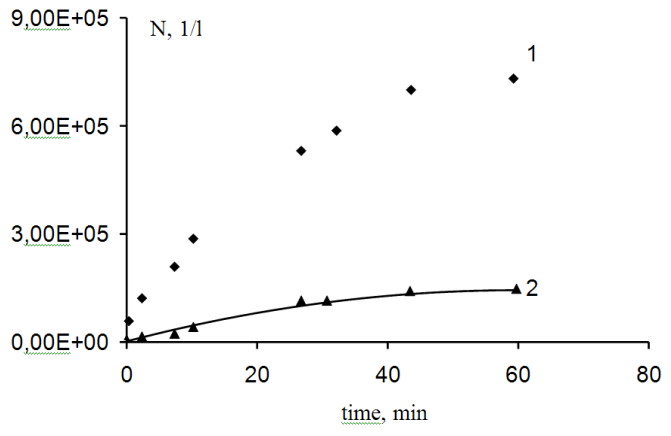

Fig. 6. Dependence of the amount of yeast cells agglomerates per unit volume of the system at the initial concentration of yeast 8 (1) and 1.6 (2) g/l. Experimental data are marked by points, the theoretical curves are constructed according to Eq. (8)

The kinetic model makes it possible to calculate the dependence of the amount of agglomerates of microorganisms in unit volume of the system from the duration of ultrasonic treatment by Eq. (8):

$$
N=N_{1}-\left(N_{1}-N_{i n}\right) \exp (-k t)
$$

Experimental data on the dependence of the number of agglomerates per unit volume of the system (Fig. 6) are well described by Eq. (8), the theoretical curves reach a maximum in approximately 60 mins after the start of ultrasound treatment.

Eq. (4) allows us to calculate the total area of the cell surface that participates in the formation of agglomerates. As can be seen from Fig. 7, the total surface area of yeast cells participated in the formation of cell agglomerates per unit volume of the system decreases during ultrasound treatment by practically zero in $60 \mathrm{~min}$. The theoretical curve obtained by Eq. (4) coincides well with the experimental data. 


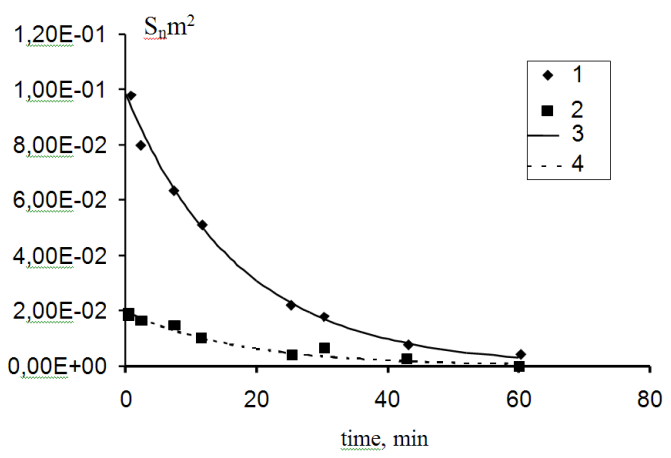

Fig. 7. Dependence of the total area of the surface of the yeast cells participated in the formation of cell aggregates per unit volume of the system at the initial concentration of yeast $8(1,3)$ and $1.6 \mathrm{~g} / \mathrm{l}(2,4)$. Experimental data is indicated by the points $(1,2)$, the theoretical data $(3,4)$ is constructed according to Eq. (4)

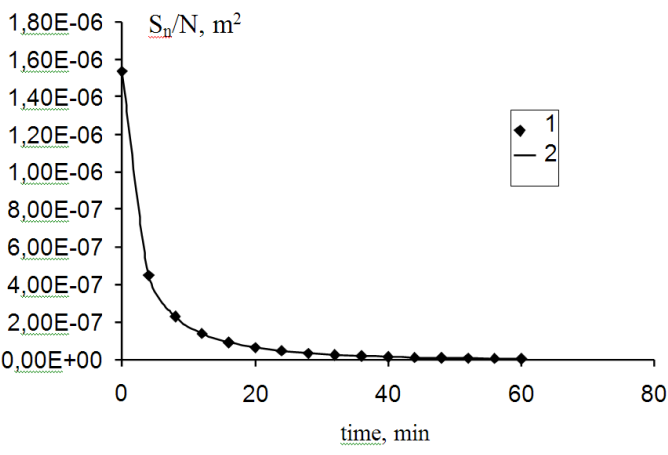

Fig. 8. Dependence of the average surface area of the yeast cells participated in the formation of cell agglomerates per unit volume of the system at the initial concentration of yeast 8 (1) and 1.6 (2) g/l
The obtained experimental data allow us to calculate the average surface area of the cell, which forms bonds with adjacent cells in the agglomerate by the equation:

$$
S_{n 1}=S_{n} / N
$$

Fig. 8 shows data on the change in the surface area of the cell in the agglomerate that participates in its formation, obtained by Eq. (9). Fig. 8 shows that the change in the average surface area that binds the cell to the agglomerate decreases with the same speed when processing the system by ultrasound and after $60 \mathrm{~min}$ of processing practically reaches zero regardless of the initial concentration of yeast in the system.

\section{Conclusions}

Ultrasonic technology is an effective method to enhance clusters of microorganism decomposition and to increase the concentration of viable microorganisms in dispersion. Investigations of a number of viable microorganisms in water dispersion during sonication have shown that their concentration increased during first $30 \mathrm{~min}$ till maximum. Then their quantity sharply decreased in comparison with untreated cells. A kinetic model of ultrasonic degradation of yeast cells aggregate was proposed. This model describes decomposition of yeast aggregates with the formation of single microorganisms or small cells aggregates during sonication. The kinetic model makes it possible to calculate the dependence of the amount of agglomerates of microorganisms in unit volume of the system from the duration of ultrasonic treatment.

\section{Acknowledgments}

This work was supported by Lviv Polytechnic National University and Department of General Chemistry.

\section{References}

[1] Goncharuk V., Malyarenko V., Yaremenko V.: J. Water Chem. Technol., 2008, 30, 137. https://doi.org/10.3103/S1063455X08030028 [2] Malyovanyy M, Sakalova G., Chornomaz N., Nahurskyy O.: Chem. Chem. Technol., 2013, 7, 355.
[3] Malovanyy A., Plaza E., Trela J., Malovanyy M.: Water Sci. Technol., 2014, 70, 144. https:doi.org/10.2166/wst.2014.208 [4] Starchevskyy V., Bernatska N., Typilo I., Khomyshyn I.: Chem. Chem. Technol., 2017, 11, 358. https://doi.org/10.23939/chcht11.03.358

[5] Mason T., Cobley A., Graves J.: Ultrason. Sonochem., 2011, 18, 226. https://doi.org/10.1016/j.ultsonch.2010.05.008

[6] Jambrak A., Mason T., Lelas V. et al.: J. Food Eng., 2014, 121, 15. https://doi.org/10.1016/j.jfoodeng.2013.08.012

[7] Melnyk L., Bessarab O., Matko S., Malyovanyy M.: Chem. Chem. Technol., 2015, 9, 467. 10.23939/chcht09.04.467

[8] Shmandiy, V., Bezdeneznych, L., Kharlamova A., Svjatenko, Malovanyy M., Petrushka K, Polyuzhyn I.: Chem. Chem. Technol., 2017, 11, 242. https://doi.org/10.23939/chcht11.02.242

[9] Vasilyak, L.: Eng. Appl. Electrochem., 2010, 46, 489. https://doi.org/10.3103/S1068375510050133 [10] Tulaydan, Y., Malovanyy, M., Kochubei, V., Sakalova H.: Chem. Chem. Technol., 2017, 11, 463. doi.org/10.23939/chcht11.04.463

[11] Starchevskyy V., Pohrebennyk V., Bernatska N.: Bezpeka Vody. Bristol, Mykolaiv 2016.

[12] Ashokkumar M., Sunartio D., Kentish S. et al.: Innovat. Food Sci. Emerg. Technol., 2008, 9, 155. https://doi.org/10.1016/j.ifset.2007.05.005

[13] Bermúdez-Aguirre D., Mobbs T., Barbosa-Cánovas G.: [in:]

Feng H., Weiss J., Barbosa-Canovas G. (Eds.), Ultrasound

Technologies for Food and Bioprocessing, 2010, 65-105. https://doi.org/10.1007/978-1-4419-7472-3_3

[14] Baranova V., Bibic E. et al.: Rukovodstvo po Kolloidnoi Khimii. Vysshay shkola, Moskva 1983.

Received: December 12, 2017 / Revised: January 04, 2018 / Accepted: March 12, 2018

\section{ВИЗНАЧЕННЯ ВПЛИВУ КАВІТАЦІЇ НА ПРОЦЕС РУЙНУВАННЯ АГЛОМЕРАТІВ КЛІТИН МІКРООРГАНІЗМІВ}

Анотація. Досліджено вплив кавітації на зменшення кількості колоній мікроорганізмів. Показано, що кількість вегетуючих мікроорганізмів у водній дисперсії протягом перших 30 хвилин оброблення ультразвуком збільшилась до максимуму. Встановлено, що подальша дія ультразвуку призводить до їх різкого зменшення. Запропоновано кінетичну модель ультразвукового руйнування агрегатів клітин дріжджів.

Ключові слова: ультразвук, Saccharomyces cerevisiae, руйнування мікроорганізмів, агломерати дріжджових клітин, кінетика реакиї. 